\title{
A Research on the Diversification of Financing Modes of Real Estate Enterprises in China
}

\author{
Weiwei Zhang* \\ School of Management Science and Engineering \\ Shandong Institute of Business and Technology \\ Yantai, China \\ zwwc507@163.com \\ *Corresponding author
}

\author{
Hengliang $\mathrm{Wu}$ \\ School of Management Science and Engineering \\ Shandong Institute of Business and Technology \\ Yantai, China
}

\begin{abstract}
In recent years, the government has implemented a series of severe macro-economic regulation policy, especially monetary policy, on the real estate industry. It is more and more difficult to acquire bank loans for most real estate enterprises. Financing difficulties become the critical problem that limits the development of real estate industry. Single financing mode will not meet the need of funds. This research tries to find some innovative and diverse financing modes for the sustainable development of the real estate industry.
\end{abstract}

Keywords- low-income housing; innovative modes; capitalintensive; project finance; welfare lottery; real estate

\section{INTRODUCTION}

Real estate is a typical capital-dependent industry, so a plentiful and stable financial support is crucial to its development. And the macroeconomic changes and the guidance of fiscal and monetary policy exercise a great influence on the scale and mode of the real estate financing [1]. With the reform of Chinese type of finance \& investment and the adjustment of state macro industry policy, fund chains of real estate enterprises are confronted with unprecedented challenge. How to solve the capital bottleneck is becoming the critical question to real estate industry. At present, real estate firms' excessive dependence on the loans of the commercial bank has lead to that the financing channel is too single. So the fluctuation within macroeconomic conditions, especially from monetary policy viewpoint, will influence and limit the development of the real estate industry [2]. Therefore, the research about the diversification of real estate financing models is necessary and urgent for the real estate industry.

According to the market participants' differences, China's real estate market falls into two parts: commercial housing market and low-income housing market. Most of previous studies about real estate firms financing focus only on financing for commercial housing development. In fact, the low-income housing problem has attracted increasing amount of social attention, and government has implemented lowincome housing projects on a large scale. As national financial pressures are expected to grow, we will need broader source of funding. So this paper takes into account these two sub-topics. Based on the analysis of traditional financing models for housing financing market, the paper makes theoretical discussion in innovative financing models and discusses the feasibility of diverse financing channels.

\section{TRADITIONAL FINANCING MODES FOR HOUSING FINANCING}

Real estate market in China starts relatively late, and the financing market is imperfect, so most real estate enterprises especially small businesses depend on traditional financing models. The traditional financing models which are being used now include bank loans, equity financing, financing by listing, corporate bond, etc. They will be introduced briefly in following:

\section{A. Bank loans}

Bank loan is the most traditional financing mode, also most important channel for most real estate enterprises so far. According to statistics, real estate projects sourced about $60 \%$ of the fund directly or indirectly from banks. Strong dependence on bank loans for financing real estate increase both real estate market risk and commercial banks credit risk. Main forms of bank loan include real estate project development loans, circulating fund loans, individual mortgage loans, credit loans, etc.

From statistics data of real estate project development loans, we can see that tight regulation of the real estate credit policies has reduced the proportion of domestic loans in the fund of real estate enterprises (see Fig. 1).

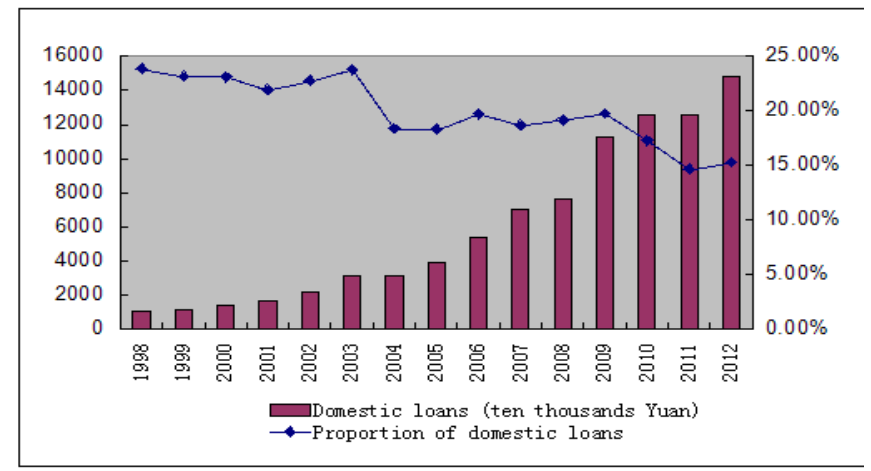

FIGURE I. DOMESTIC LOANS AND PROPORTION IN REAL ESTATE DEVELOPMENT FUND

(1) Data source: Wind Database.

(2)Data source: China Real Estate Development Report; China's National Bureau 


\section{B. Equity Financing}

Equity financing can lower debt burden and financing risk, but in order to get financed, the developers have to give out a large part of profits and power [3]. Especially for good projects, many real estate enterprises are not willing to attract funds through capital and equity increase.

\section{Financing by Listing}

Another attractive way to acquire equity capital is IPO (initial public offering), which is a fast financing method through listing in the stock market to raise large amount of funds. But the threshold of IPO in domestic stock market is too high for most enterprises, so some enterprises prefer listing in overseas market. In addition, back-door listing is the next choice for some enterprises, though attractive shell resource is not easy to obtain [4]. Due to high threshold and numerous restrictions, listing constitutes only a modest proportion of real estate funds.

\section{Corporate Bond}

This is also a financing method through the stock market to raise funds, which is often used for higher return rate projects. According to Securities Law, the requirements on issuing bond are rather strict, which limits the application of this mode and denies the chance of many small enterprises. Besides, complex procedure and high cost of issuing corporate bond stop the advance of many enterprises.

\section{INNOVATIVE FINANCING MODES FOR HOUSING FINANCING}

The lack of financial products limits the development of real estate industry, and the market calls for more steady suitable funding solutions. Especially, as the quasi-public goods, most of the low-income housing projects are lowprofit ones, which mainly rely on government financing funds. So there is increasing pressure and a growing gap in financial funds. To raise funds from multiple sources for both commercial housing and low-income housing projects and actively explore innovative financing modes has become the urgent issue for the development of real estate market.

\section{A. Innovative Financing Modes for Commercial Housing Financing}

1) Project financing: Project financing is fund arrangement in which the repayment is derived primarily from the project's cash flow, not the revenue of other business or assets of sponsor. But the project's assets, rights, and interests are usually held as collateral. This model will be workable for those real estate enterprises who has high return rate projects, but whose asset-liability ratio is too high to acquire new credit loan. If the developer has more than one project at the same time or more than one developer sponsor projects together, project financing model is a prior choice, as shown in Fig. 2. Under such circumstances project financing is an effective way to lower the risk and cost of funding, and the fund is easy to withdraw when projects are completed. But if such projects may not generate enough or stable cash flow for either the principal or interest payments as predicted, fund providers would have to accept higher risk than expectation. So when this mode applied, accurate feasibility study is critical for all participants.

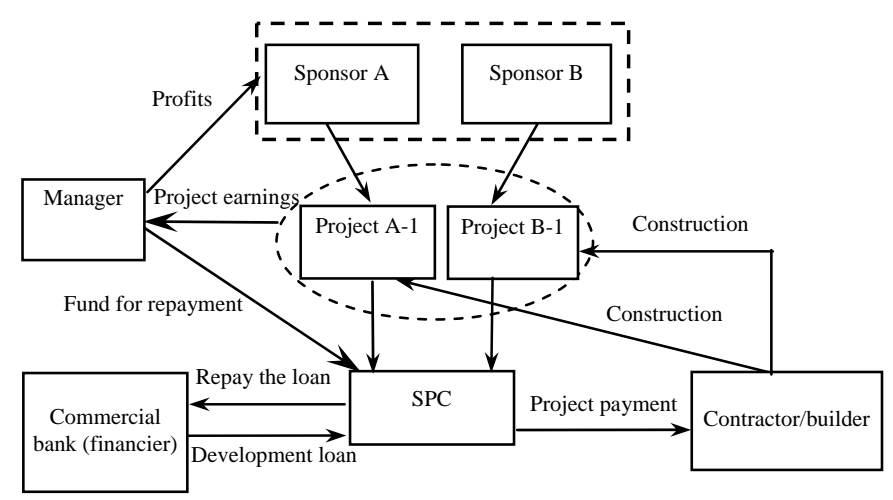

FIGURE II. SCHEME OF PROJECT FINANCE

2) Assets securitization: Assets securitization is a financial innovation tool, which develops fast within global finance field in recent years. Though many studies of domestic finance scholars have made great achievements, there are no signs of large scale expansion. Due to the imperfection of domestic financing market, there are a lot of obstacles in practice.

Assets securitization falls into two categories: credit asset securitization and revenue assets securitization, both of which can be applied in housing financing. Credit asset securitization can motivate and improve the capacity of bank lending by issuing securities backed on the credit assets of real estate project development loan, which can increase the availability of funds for real estate enterprises. By contrast, revenue assets securitization is a more direct model to finance real estate projects, as shown in Fig. 3. Many entities take part in the process of assets securitization and it's a complicated financing structure, which limits the application of this innovative method. With the development of domestic financing market, assets securitization will boom in China.

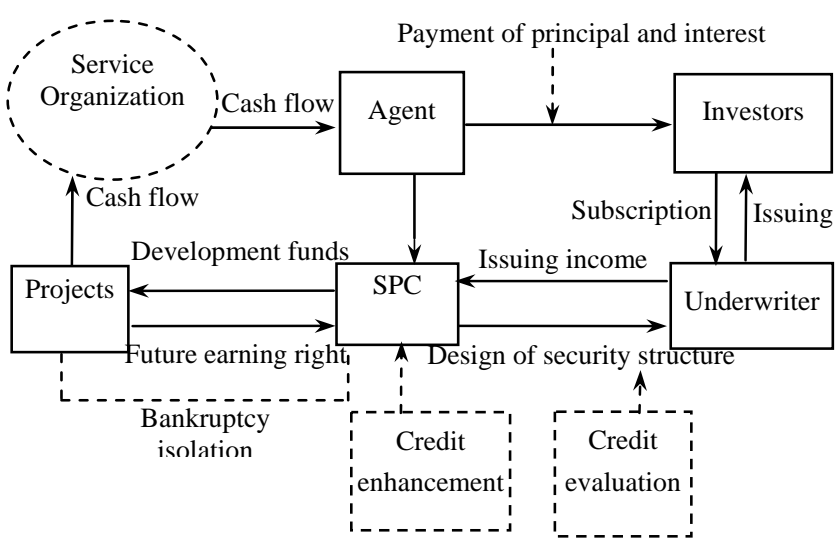

FIGURE III. MODE OF REVENUE ASSETS SECURITIZATION

\section{B. Innovative Financing Modes for Low-Income Housing Financing}

As the important component of China housing market, low-income housing' construction and development has become a significant issue in national housing policy. China' low-income housing market is facing huge demand and serious pressure on the funding gap, and the situation will last in next few years [5]. In the system of domestic low- 
income housing (see Fig. 4), this paper focus on public rental housing and low-rent housing.

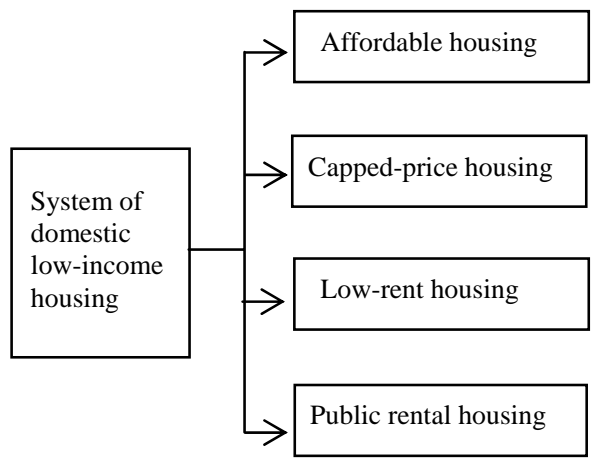

\section{FIGURE IV. SYSTEM OF DOMESTIC LOW-INCOME HOUSING}

1) BT financing mode: BT (Building-Transfer) is a derivative form of BOT. This mode can resolve the fiscal difficulty in funding to carry on the project construction at early stage. When transferred, housing projects can be launched to the market immediately and the fund would withdraw from low-income housing projects to pay the bills to BT contractor. The key point in this mode is the selection of an excellent contractor and the price contract. This mode can be applied to affordable housing and capped-price housing projects, but not to low-rent housing or public rental housing.

2) REITS mode:Real Estate Investment Trusts (REITS) originated in US, and has emerged as a globally popular investment product. REITS were introduced into China in recent years, and become a new investment tool of financing market. Meanwhile, REITS will become a helpful vehicle to fund for real-estate industry in China [6]. Contrast to commercial housing projects, this mode is more suitable for public rental housing and low-rent housing projects with stable cash flow, but low risk. REITS will enable the government to pool large-scale organization funds and civil funds to the housing system to meet growing needs of lowincome groups [7].

3) PPP financing mode: PPP is acronym of PublicPrivate-Partnership, which has been widely applied in some developed countries, but a newly rising way in domestic market. The main participants in this mode include two parts : government's public department and private department, the former represents public interests Recent years, some infrastructure constructions have begun the application of PPP mode. Considering the characteristics of low-income housing projects, we can apply PPP in such project construction. In PPP mode, Partner Company can construct new houses or purchase existing houses, and then operate these houses to earn profits in limited concession period, and at the end, Partner Company will deliver the projects to government. Fig. 5 shows the example of PPP's operation procedure in financing public rental housing projects. PPP would be proved one of the suitable modes for low-income housing projects.

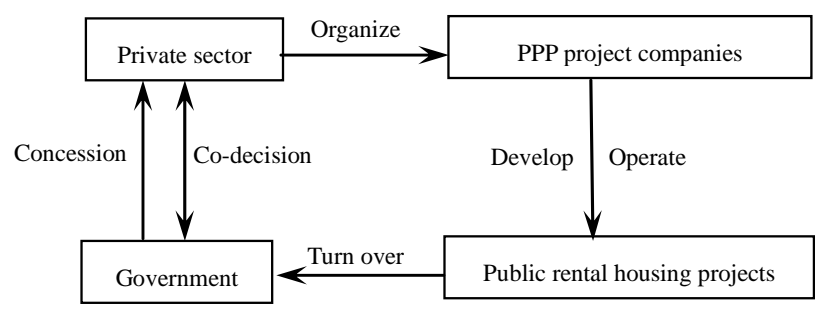

FIGURE V. OPERATION PROCEDURE OF PPP IN PUBLIC RENTAL HOUSING PROJECTS

\section{CONCLUSION}

Domestic real estate market is going through difficult times, and capital is a determining factor for the survival of any enterprise, which must explore new financing ways. Any single mode can not support long-term and sustainable development of enterprises. Diversification of financing vehicle is necessary. Other channels can also provide funds for current housing market, e.g. housing accumulation fund, pension funds, endowments and fund collected through the issuance of welfare lottery, etc. Given capital source stability and current situation of housing, these channels are feasible theoretically, but the specific implementation methods need further research.

\section{ACKNOWLEDGMENTS}

The author would like to thank the grant of the Shandong Province Social Science Planning and Research Project (No.12DGLJ07), Shandong Province Higher Educational Humanities and Social Sciences Research Project (No.J10WG64), and all collaborators who provided the data sources for my previous and current studies.

\section{REFERENCES}

[1] Terrence Claurefie, "Stacy Sermons Real estate finance theory and practice”, New York: Prentice Hall, 1999.

[2] Alan Rabinowitz, "The Real Estate Gamble: Lessons from 50 years of Boom and Burst”, 1980.1

[3] Hancock D, "Wilcox J A bank capital, nonblank finance, and real estate activity”, Journal of Housing Research., pp.75-105, 1997.8(1).

[4] Su keqiang, "On Financing Models of Real Estate Enterprise" , China's Foreign Trade, pp.56-58, 2011.11.

[5] Peter Werwath, "Financing Mechanisms for Affordable Housing", Enterprise Community Partners, Inc, 2007.

[6] Ernst\&Young PLL, “The Future of REITs in China”, pp.9-15,2011.3.

[7] “The Investor Guide to REITs", National Association of Real Estate Investment Trusts, NAREIT, 2009. 